\title{
Alternative seed treatment methods for plant pathogen control in sweet pepper crops
}

\author{
Geusa Fonseca Dourado ${ }^{1} \oplus$, Mônica Shirley Brasil dos Santos e Silva ${ }^{1} \oplus$, Anna Christina Sanazário de Oliveira ${ }^{1} \oplus$, \\ Erlen Keila Cândido e Silva ${ }^{1} \odot$, Leonardo de Jesus Machado Góis de Oliveira ${ }^{1} \oplus$, Antonia Alice Costa Rodrigues $^{1}[$

\footnotetext{
1 Universidade Estadual do Maranhão, São Luis, MA, Brasil. E-mail: geusadourado@gmail.com; shirleybrasil.85@hotmail.com; annasanazario@gmail.com; erlenkeila@yahoo.com.br; leonnardo_jesus@hotmail.com; aacrodrigues@outlook.com
}

ABSTRACT: The health and physiological quality of sweet pepper seeds were assessed along with the use of alternative methods by heat therapy, plant extracts, chemical and biological products to control plant pathogens associated to the seeds. The in vitro experiments assessed the effect of the treatments applied to the seeds to control the identified plant pathogens. After treatment, the seeds were plated, incubated and assessed after seven days. An in vivo experiment was also carried out with the treatments that presented the best plant pathogen control in the seeds, which were treated and sown and after 30 days the plants were sprayed with a C. gloeosporioides suspension. The severity was assessed by a score scale specific to the pathogen system. The treatments with best plant pathogen control in the seeds were aqueous basil extract $5 \%$, heat therapy $45^{\circ} \mathrm{C} / 25$ minutes, Thiophanate methyl, Quality ${ }^{\circledR}$ and B. methylotrophicus isolate, MGSS 274. In anthracnose management, the basil extract, MGSS 274 and Quality ${ }^{\circledR}$ reduced disease severity in sweet pepper plants.

Key words: anthracnose; biological agents; heat therapy; plant extracts; seeds health

\section{Métodos alternativos de tratamento de sementes no controle de fitopatógenos na cultura do pimentão}

RESUMO: O objetivo deste trabalho foi avaliar a qualidade sanitária e fisiológica de sementes de pimentão e o uso de métodos alternativos via termoterapia, extratos vegetais, produtos químicos e biológicos, no controle dos fitopatógenos associados a essas sementes. Os experimentos in vitro consistiram na avaliação do efeito dos tratamentos aplicados nas sementes no controle dos fitopatógenos identificados. Após tratadas, as sementes foram plaqueadas, incubadas e avaliadas após sete dias. Também foi conduzido experimento in vivo com os tratamentos que apresentaram melhor controle dos fitopatógenos nas sementes, estas foram tratadas e semeadas e, após 30 dias, as plantas foram pulverizadas com suspensão de $C$. gloeosporioides. Para avaliação da severidade adotou-se escala de nota específica para o patossistema. Os tratamentos com melhor controle de fitopatógenos nas sementes foram extrato aquoso de manjericão $5 \%$, termoterapia $45^{\circ} \mathrm{C} / 25$ minutos, Tiofanato Metílico, Quality ${ }^{\circledR}$ e o isolado de B. methylotrophicus, MGSS 274. No manejo da antracnose, o extrato de manjericão, o isolado MGSS 274 e o produto Quality ${ }^{\circledR}$ promoveram redução da severidade da doença em plantas de pimentão.

Palavras-chave: antracnose; agentes biológicos; termoterapia; extratos vegetais; sanidade de sementes 


\section{Introduction}

The sweet pepper (Capsicum annum L.) belongs to the family of the Solanaceus. It is very important socially and economically in Brazil, because it is one of the most consumed vegetables and cultivated throughout the country (Monteiro Neto et al., 2016). The cropping area is approximately 13,000 ha and fruit production is about 350.000 tons (Abrafrutas \& CNA, 2018). One of the main bottlenecks to its production is disease occurrence in the crop (Trecha et al., 2017).

Vegetables are usually susceptible to disease, especially those transmitted by seeds. Seeds are one of the main means of pathogen survival and dispersion (Pereira et al., 2015). Anthracnose is a highly destructive disease that affects several crops, including the sweet pepper and the causal agent is the fungus Colletotrichum gloeosporioides (Penz) (Araújo et al., 2016). Other plant pathogens are also found in association with sweet pepper seeds, such as the genera Aspergillus spp., Penicillium spp. and Rhizopus sp., described in the literature as having the potential to deteriorate grains and seeds and produce mycotoxins highly toxic to people, animals and plants (Reverberi et al., 2010).

Seed health can be affected by the joint action of plant pathogenic fungi that cause harm and also hinder crop development (Santos et al., 2016). They can also reduce the physiological quality with negative impacts on germination and further damage the results of studies, carried out under laboratory conditions (Cunha et al., 2017).

A relevant aspect of health quality is healthy seeding production, because seeds are susceptible to attack from plant pathogens that cause deterioration, wounds and anomalies in the seedlings (Piveta et al., 2010). Another aspect is the control of seed-transmitted diseases, because of the need to reduce and prevent transmission over long distances which can be achieved through seed health treatment, that can reduce and control the disease causal agents diseases without damaging the physiological potential (Braga et al., 2010; Flávio et al., 2014). Thus, the use of alternative controls, such as biological and physical methods, in addition to chemical methods, have presented significant results in eliminating or reducing the infective inoculum from plant pathogens in seeds (Santos et al., 2016).

In this context, the aims of the present study was to assess the health and physiological quality of sweet pepper seeds and the use of alternative methods, such as heat therapy, plant extracts, chemical and biological products to control plant pathogens in these seeds.

\section{Materials and Methods}

The experiments were carried out in the Plant Pathology Laboratory and in a greenhouse. Seeds of the sweet pepper cultivar All Big were used for the experiments.

Health quality: assessed by the Blotter Test (Brasil, 2009) method, by plating 400 seeds, divided in eight 50seed replications. The following were assessed in the fungal population: germinated seeds $(G)$ and non-germinated seeds (NG); healthy seeds (S) and contaminated seeds (C). The nongerminated seeds were considered as dead seeds. The data were expressed in incidence percentage.

Physiological quality: the standard germination, vigor and moisture test was carried out according to RAS (Brasil, 2009) and assessed by counting normal seedlings, abnormal seedlings and affected seedings, at seven and 14 days after installation. The seed vigor was obtained by the first germination count test, carried out simultaneously with the standard germination test, assessed by the percentage of normal seedlings on the seventh day after sowing. At the end of the standard germination test using the daily data of the number of normal seedlings, the germination speed index was calculated according to Maguire (1962). The seed moisture degree was determined by the chamber method at $105{ }^{\circ} \mathrm{C}$, for 24 hours, with two replications, according to RAS (Brasil, 2009).

Heat therapy: the seeds were disinfected, placed in polyamide net bags and transferred to a water bath. The combinations of time and temperature applied to the seeds were based on the pre-determined combination for the sweet pepper crop (Zambolim et al., 1997). The treatments were the following: 45 ㅇ C/25 min., 45ㅇ C/30 min., 50 C/ 25 min., 50ㅇ $\mathrm{C} / 30 \mathrm{~min}$., $550 \mathrm{C} / 25 \mathrm{~min}$. and 55 $\mathrm{C} / 30 \mathrm{~min}$. Untreated seeds were kept as control. After the treatments, the seeds were placed on petri dishes containing BSA (potato-saccharineagar) culture medium and kept in a BOD chamber at $25 \pm 2$ 응 C. After seven days the fungal colonies were assessed. A complete randomized design was used with seven treatments, five replications and the experimental unit consisted of one dish, containing 20 seeds.

Plant extracts: leaves of nim (Azadirachta indica A. Juss), eucalyptus (Eucalyptus citriodora Hook), cinnamon (Cinnamomum zeylanicum Blume) and basil (Ocimum basilicum L.) were dried, ground and immersed in distilled water for 24 hours to extract the compounds. They were then filtered through gauze, centrifuged for two minutes at 1,800 rpm and again filtered through filter adapted in a syringe with a $22 \mu \mathrm{m}$ cellulase membrane. Aqueous extracts were prepared at $5 \%$ ( $50 \mathrm{~g}$ extract $\mathrm{L}^{-1}$ distilled water) concentration in which the seeds, after disinfection, were immersed for a period of 10 minutes. The seeds were then plated in BSA culture medium and incubated at $22 \pm 2{ }^{\circ} \mathrm{C}$, under a 12 hours light/12 hours dark regimen. The pathogen incidence was assessed after seven days by examining the seeds individually under a stereoscopic microscope to observe and identify the plant pathogens. A complete randomized design was used with five treatments and five replications. The control was seeds immersed in distilled water.

Chemical and biological products: first 700 seeds were disinfected before being submitted to the treatments, through triple washing, by immersion, lasting one minute in each solution: $70 \%$ alcohol; sodium hypochlorite ( $\mathrm{NaOCl}$ ) in a 3:1 ratio; and, distilled water. The treatments used were the chemical methods with the products Thiophanate methyl (70 g p.c 100 
$\left.\mathrm{L}^{-1}\right)$, Tebuconazole (100 mL p.c $\left.100 \mathrm{~L}^{-1}\right)$, Carbendazin $(100 \mathrm{~mL}$ p.c in $400 \mathrm{~mL}$ water $100 \mathrm{~kg}^{-1}$ seeds) and Azoxystrobin+Thiram (200 g p.c $100 \mathrm{~kg}^{-1}$ seeds) and with commercial biological products based on Trichoderma asperellum (Quality ${ }^{\circledR} 100$ g p.c $600 \mathrm{~mL}^{-}$ $\left.{ }^{1}\right)$ and Bacillus subtillis (Rizos ${ }^{\circledR}-50 \mathrm{~mL}$ ) at doses recommended by the manufacturers. The fungicides and seeds were placed in $2.0 \mathrm{~L}$ plastic bags and shaken for ten minutes until the seeds were completely covered by the fungicide. The manufacturers' recommendations were followed in the treatments with the biological products. The seeds were then plated in BSA culture medium and kept in a BOD chamber at $25 \pm 2{ }^{\circ} \mathrm{C}$. Assessment consisted of observing the fungus colonies using a stereoscopic microscope seven days after plating. A complete randomized block design was used with seven treatments and five replications. The control was seeds immersed in distilled water.

Microbiolization with Bacillus spp. isolates: the following isolates were used for biological control: Bacillus spp., MGSS 271 (Bacillus cereus), MGSS 274 (B. methylotrophicus), MGSS 272 (B. polymyxa), MGSS 275 (Bacillus sp.) and MGSS 273 (B. pentothenticus). The isolates were obtained from the "Prof. Gilson Soares da Silva" Plant Pathogen Collection. The methodology by Ludwig et al. (2007) was adopted for the treatment that consists in prior culture of the isolates in BDA (potato-dextrose-agar), culture medium for 48-hours, followed by seed microbiolization in bacteria suspension, prepared with saline solution $(\mathrm{NaCl} 0.85 \%)$ and agitated for 30 minutes. Shortly afterwards the seeds were plated on petri dishes and BSA culture medium and kept in a BOD chamber at $25 \pm 2^{\circ} \mathrm{C}$. After seven days the fungus colony incidence was assessed, using a stereoscopic microscope. A complete randomized design was used with six treatments and five replications, and the control seeds were immersed in distilled water.

Anthracnose management: the treatments used were heat therapy $\left(45^{\circ} \mathrm{C} / 25\right.$ minutes), aqueous basil extract, MGSS 274 , the Quality ${ }^{\circledR}$ biological product $\left(0.167 \mathrm{~g}\right.$. $\left.\mathrm{mL}^{-1}\right)$; Thiophanate

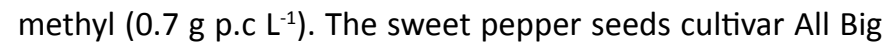
were submitted to the treatments and then sown in plastic pots containing previously autoclaved soil and thinned to 2 plants/ pot. Thirty-day old plants were inoculated by spraying with a conedium suspension of Colletotrichum gloeosporioides at a concentration of $10^{-6}$ conidia $\mathrm{mL}^{-6}$, and kept in a wet chamber for 48 hours. The severity was assessed on all the plant leaves at 3, 8, 13, 18 and 23 days after inoculation using the scale of scores described by Pereira et al. (2011), adapted by Araújo et al. (2016): score 1: plants without symptoms; score 2: 1 - 10\% plants with symptoms; score 3: $11-25 \%$ plants with symptoms; score 4: 26 - 50\% plants with symptoms; score 5: $51-75 \%$ plants with symptoms; score 6: more than $75 \%$ plants with symptoms and/or plant death. The severity data were transformed in disease index (McKinney, 1923) and used to calculate the area under disease progress curve (AUDPC), with the formula:

$$
\operatorname{AUDPC}=\Sigma\left[\left(\mathrm{Y}_{\mathrm{i}}+\mathrm{Y}_{\mathrm{i}+1}\right) / 2\right] \cdot\left(\mathrm{T}_{\mathrm{i}+1}-\mathrm{T}_{\mathrm{i}}\right)
$$

where $Y_{i}+Y_{i+1}$ are the severity values observed among consecutive assessments and $T_{i+1}-T_{i}$, is the time interval between the assessments (Shaner \& Finney, 1977). A complete randomized design was used with six treatments and five replications, and the plot consisted of two plants per plot.

Statistical analysis of the data: the data was submitted to analysis of variance and the means of each treatment compared by the Tukey test $(p<0.05)$. The software InfoStat/ IS (Di Rienzo, 2018) was used for the statistical analyses. The data in percentage were transformed by the $\mathrm{V} x$.

\section{Results and Discussion}

Sweet pepper seed health and physiological quality

The health assessment showed that $31 \%$ of the seeds were contaminated with the largest incidence being Rizopus stolonifer (22\%) followed by Aspergillus niger (19\%) and A. flavus (15\%). The lowest incidences were of Phoma sp. and Fusarium sp. with only $3 \%$ and $7 \%$, respectively (Figure 1).

Table 1 shows the results obtained in the physiological quality assessment of the sweet pepper seeds, cultivar All Big.

A total of $97 \%$ of the seeds of the sweet pepper cultivar All Big germinated. A similar result was found by Vieira et al. (2018) who also observed over $90 \%$ germination for this cultivar. The assessment of normal seedlings, in the first count, showed average vigor (69\%) but in the count at 14 days very high vigor (96\%). Corroborating with these results Torres \& Minami (2000) in an experiment with four batches of the All Big cultivar obtained at the first count vigor $41 \%$ to $7 \%$ and at 14 days, 74 to $89 \%$ of normal seedlings. Differently, Vieira et al. (2018) obtained very low vigor for this cultivar that by 14 days reached only $6.5 \%$ normal seedlings.

The results of the present research showed that $31.5 \%$ of the seeds were infected but there was no interference in
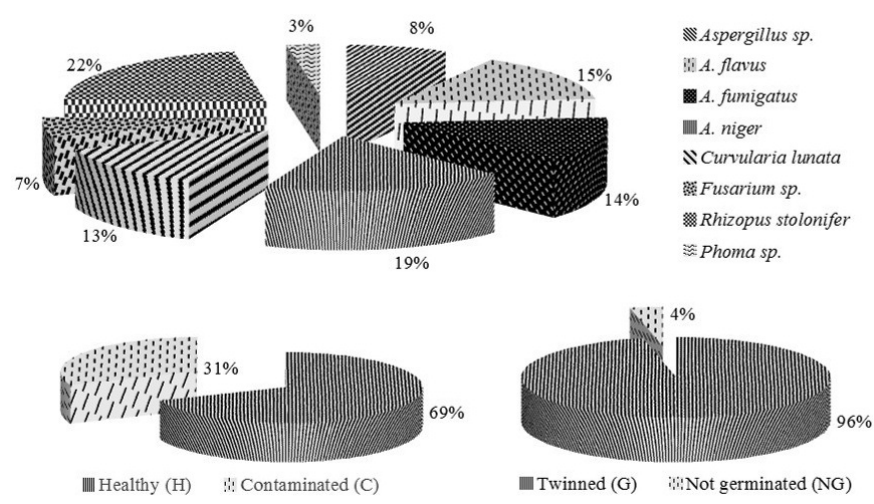

Figure 1. Health assessment of seeds of the sweet pepper variety All Big, by the Blotter Test method, 2017.

Table 1. Assessment of sweet pepper All Big seed physiological quality by the germination, moisture and vigor test, 2017.

\begin{tabular}{ccccccc}
\hline Germination & FC & M & NS & AS & IS & \multirow{2}{*}{ GSI } \\
\hline & & $(\%)$ & & & & \\
\hline 97.00 & 69.00 & 8.07 & 96.00 & 4.00 & 31.50 & 40.10 \\
\hline
\end{tabular}

Where first count (FC), moisture (M), normal seedlings (PN), abnormal seedlings (AS), infected seedlings (IS) and germination speed index (GSI). 
physiological quality. Thus it is emphasized that the presence of these pathogens in seeds does not always imply loss of physiological quality such as the association of the genera Aspergillus spp. e Rhizopus spp., in lettuce and cabbage seeds, that did not influence germination (Paiva et al., 2016) and further Aspergillus niger (Rapper \& Fennel), Aspergillus sp. (Micheli.) and Cladosporium cladosporioides (Fresen.) in the common bean (Phaseolus vulgaris L.) that did not interfere in the percentage of normal seedlings due to seedling defense strategies during germination (Ferreira et al., 2017). But the presence of these pathogens may guarantee survival and dissemination.

The association of pathogens in seeds may trigger a series of complications and even cause intolerable damage, given its potential for transmitting various pathogens such as fungi, bacteria, virus and nematodes, which shows the relevance of seeds with pathogen means of survival and dispersion (Pereira et al., 2015).

The results found in the present research demonstrated the use of sweet pepper seeds cultivar All Big may guarantee good stand performance, bearing in mind the high vigor obtained.

\section{In vitro treatment with heat therapy}

The heat treatments significantly reduced the incidence of all the identified plant pathogens, especially at temperatures of $45^{\circ} \mathrm{C}$ to $55^{\circ} \mathrm{C}$ during the times of 25 minutes and 30 minutes (Table 2). In a similar study, Costa et al. (2011) treated cherry tomato seeds with water heated to $50{ }^{\circ} \mathrm{C}$ for 25 minutes and 30 minutes and reported that 30 minutes exposure was most efficient in reducing the plant pathogens Aspergillus sp. and Penicillium sp., and that the seed physiological quality was not affected.

Santos et al (2016) observed in soybean seeds treated at $40^{\circ} \mathrm{C}$ that the increase in exposure time to moist heat reduced the incidence of pathogenic fungi and with time over 50 minutes, obtained health greater than $95 \%$, but the increase in temperature reduced seed germination.

In the present research, the increase in temperature up to $55{ }^{\circ} \mathrm{C}$ and 30 minutes, maintained the efficiency of the treatment in reducing the plant pathogens. Moist heat at $55{ }^{\circ} \mathrm{C}$ for 30 minutes also eradicated the fungi Rhizopus sp., Aspergillus sp. and Cladosporium sp., associated to tomato seeds and lethal to the seeds at $60{ }^{\circ} \mathrm{C}$ for 30 minutes or 60 minutes (Braga et al., 2010).

In seed treatments with hot water, regardless of the species, the temperature should be restricted to between $45^{\circ}$ and $60^{\circ} \mathrm{C}$ for a maximum period of 60 minutes. However, seed sensitivity varies from species to species, from cultivar to cultivar and often from batch to batch (Braga et al. 2010), that indicates the need to carry out the germination test before applying the treatments to the seeds for planting. Therefore, in many cases divergent results are obtained in research, due to working with live organisms, subject to the action of intrinsic and extrinsic factors to express the effect caused. Thus, heat therapy, while a physical method, although it presents low tenacity, acts promptly on the seeds that resulted in the efficient control of the plant pathogens present in the sweet pepper seeds.

\section{In vitro treatment with plant extracts}

In the incidence of fungi of the genus Aspergillus sp. only the basil aqueous extract presented significant difference from the control. For the species $A$. niger, $A$. fumigatus and $A$. flavus, almost all the treatments differed statistically from the control, except for cinnamon extract for $A$. fumigatus.

Regarding the incidence of Curvularia lunata, most of the treatments differed from the control except for the basil extract. For the fungus Rhizopus stolonifer all the extracts differed from the control but not from each other. For the genus Fusarium sp. there was no significant difference between the treatments and the control. But for the genus Phoma sp. only the cinnamon extract differed significantly from the control, but did not differ from the other treatments.

Most of the aqueous extracts were able to control over $50 \%$ of all the fungi incident in the seeds (Table 2). It is pointed out that the nim extract did not control the instance of Fusarium sp., which may have been due to the presence of some byproducts in the plant that stimulated the fungus growth (Govindachari et al., 1998). In contrast, Brito \& Nascimento

Table 2. Plant pathogen control in All Big sweet pepper seeds, using heat therapy, 2017.

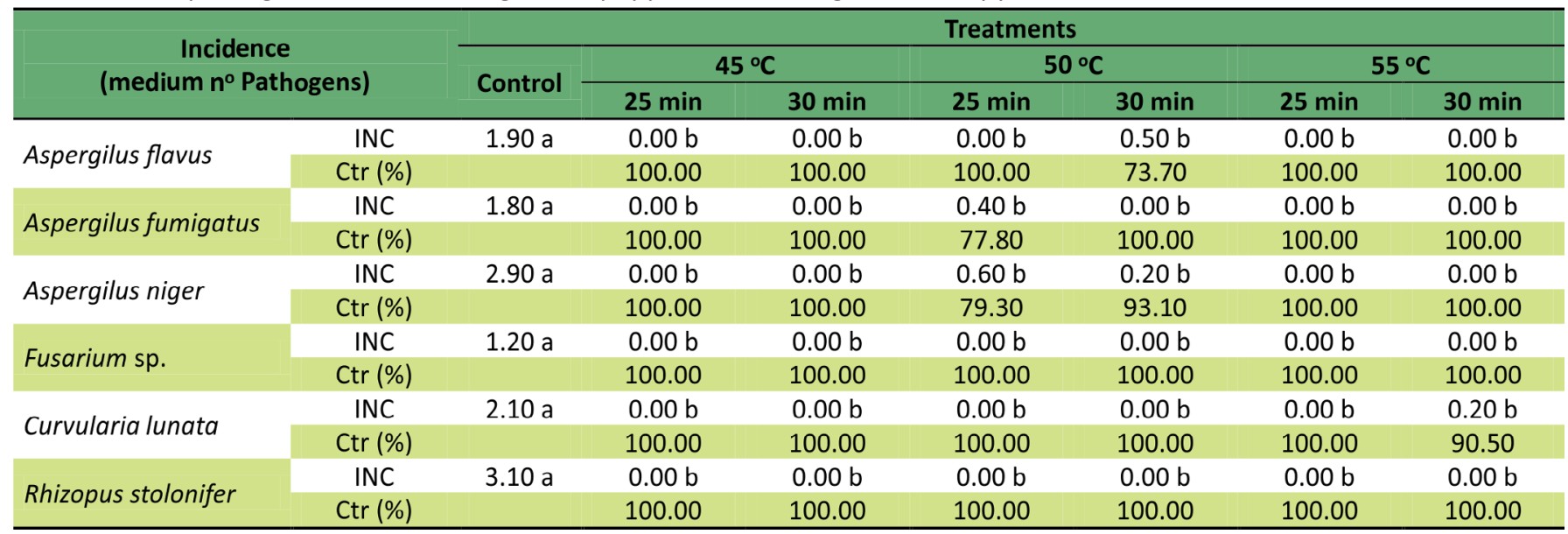

Where INC $=$ incidence, $\mathrm{Ctr}=$ control. Values followed by the same letter did not differ by the Tukey test $(p \geq 0.05)$. Data transformed by $\mathrm{V} x$. 
Table 3. Plant pathogen control in All Big sweet pepper seeds by in vitro treatment with plant extracts, 2017.

\begin{tabular}{|c|c|c|c|c|c|c|}
\hline \multirow{2}{*}{\multicolumn{2}{|c|}{$\begin{array}{c}\text { Incidence } \\
\text { (medium } n^{\circ} \text { Pathogens) }\end{array}$}} & \multicolumn{5}{|c|}{ Treatments } \\
\hline & & \multirow{2}{*}{$\frac{\text { Control }}{2.10 \mathrm{a}}$} & \multirow{2}{*}{$\frac{\text { Eucalyptus }}{1.60 \mathrm{ab}}$} & \multirow{2}{*}{$\frac{\text { Nim }}{1.10 \mathrm{ab}}$} & \multirow{2}{*}{$\begin{array}{c}\text { Cinnamon } \\
0.40 \mathrm{ab}\end{array}$} & \multirow{2}{*}{$\frac{\text { Basil }}{0.30 \mathrm{~b}}$} \\
\hline Asneraillus sn & INC & & & & & \\
\hline Aspergmus sp. & Ctr (\%) & & 23.80 & 47.60 & 80.90 & 85.70 \\
\hline \multirow{2}{*}{ A. flavus } & INC & $2.20 \mathrm{a}$ & $0.20 \mathrm{~b}$ & $0.20 \mathrm{~b}$ & $0.40 \mathrm{~b}$ & $0.00 \mathrm{~b}$ \\
\hline & $\operatorname{Ctr}(\%)$ & & 90.90 & 90.90 & 81.80 & 100.00 \\
\hline A. fumigatus & INC & $1.90 \mathrm{a}$ & $0.20 \mathrm{~b}$ & $0.00 \mathrm{~b}$ & $0.80 a b$ & $0.20 \mathrm{~b}$ \\
\hline A. niger & $\mathrm{Ctr}(\%)$ & & 57.70 & 84.60 & 100.00 & 100.00 \\
\hline \multirow{2}{*}{ Curvularia lunata } & INC & $1.40 \mathrm{a}$ & $0.20 \mathrm{~b}$ & $0.00 \mathrm{~b}$ & $0.00 \mathrm{~b}$ & $0.70 a b$ \\
\hline & $\mathrm{Ctr}(\%)$ & & 85.70 & 100.00 & 100.00 & 50.00 \\
\hline \multirow{2}{*}{ Fusarium sp. } & INC & $0.60 a b$ & $0.00 \mathrm{~b}$ & $1.00 \mathrm{a}$ & $0.00 \mathrm{~b}$ & $0.00 \mathrm{~b}$ \\
\hline & $\mathrm{Ctr}(\%)$ & & 100.00 & NC & 100.00 & 100.00 \\
\hline Rhizopus stolonifer & INC & $2.30 \mathrm{a}$ & $0.00 \mathrm{~b}$ & $0.00 \mathrm{~b}$ & $0.00 \mathrm{~b}$ & $0.00 \mathrm{~b}$ \\
\hline
\end{tabular}

Where INC $=$ incidence, $\mathrm{Ctr}=$ control, $\mathrm{NC}=$ not controlled. Values followed by the same letter do not differ by the Tukey test $(p \geq 0.05)$. Data transformed by $\mathrm{V} \mathrm{x}$.

(2015) verified the efficacy of the plant toxic effect of nim and ginger extracts at low concentrations (starting at $25 \%$ ) on Curvularia eragrostidis (P. Henn.) on inhibiting mycelial growth and sporulation, inferring that it might be a viable alternative in the control of this plant pathogen.

The plant pathogen $R$. stolonifer, in spite of its high incidence, was controlled hundred percent by all the aqueous extracts. The cinnamon extract treatment controlled $57 \%$ and up to $100 \%$ of all the fungi identified.

Studies reported in the literature confirm the results of the present study, regarding the anti-fungal capacity of the aqueous extracts. For example, in the study by Camatti-Sartori et al. (2011) with basil extract at $50 \%$ concentration, inhibited more than $40 \%$ of the plant pathogens of the genus Fusarium sp. Basil has been mentioned in the literature because of its antimicrobial activity (Wuaden et al., 2018), that is associated mainly to the compounds Eugenol and Linalol, present in its essential oils, that act on fungus and bacteria inhibition (Koroch et al., 2017). On the other hand, Flávio et al. (2014) reported the efficiency of cinnamon aqueous extract and basil essential oil at different concentrations in reducing plant pathogen incidence in sorghum seeds, especially on the fungus Curvularia, but they were toxic to the seed vigor.

In the present study, the aqueous extracts reduced plant pathogen reduction in the seeds, maybe because of the presence of biologically active compounds in extracts of eucalyptus, nim, cinnamon and basil, that denotes the potential of using these aqueous extracts as natural antifungal agents in seed treatments.

\section{In vitro treatments with chemical and biological products}

In the in vitro experiments with chemical and biological products, all the treatments differed significantly from the control, with more than $75 \%$ control for most of the pathogens in the seeds, without differences, except for the biological product Rizos ${ }^{\bullet}$, for the fungus $A$. niger, that differed from the control and the other treatments, with control of under $75 \%$ (Table 4).

Table 4. Plant pathogen control in All Big sweet pepper seeds by treatment with chemical and biological products, 2017.

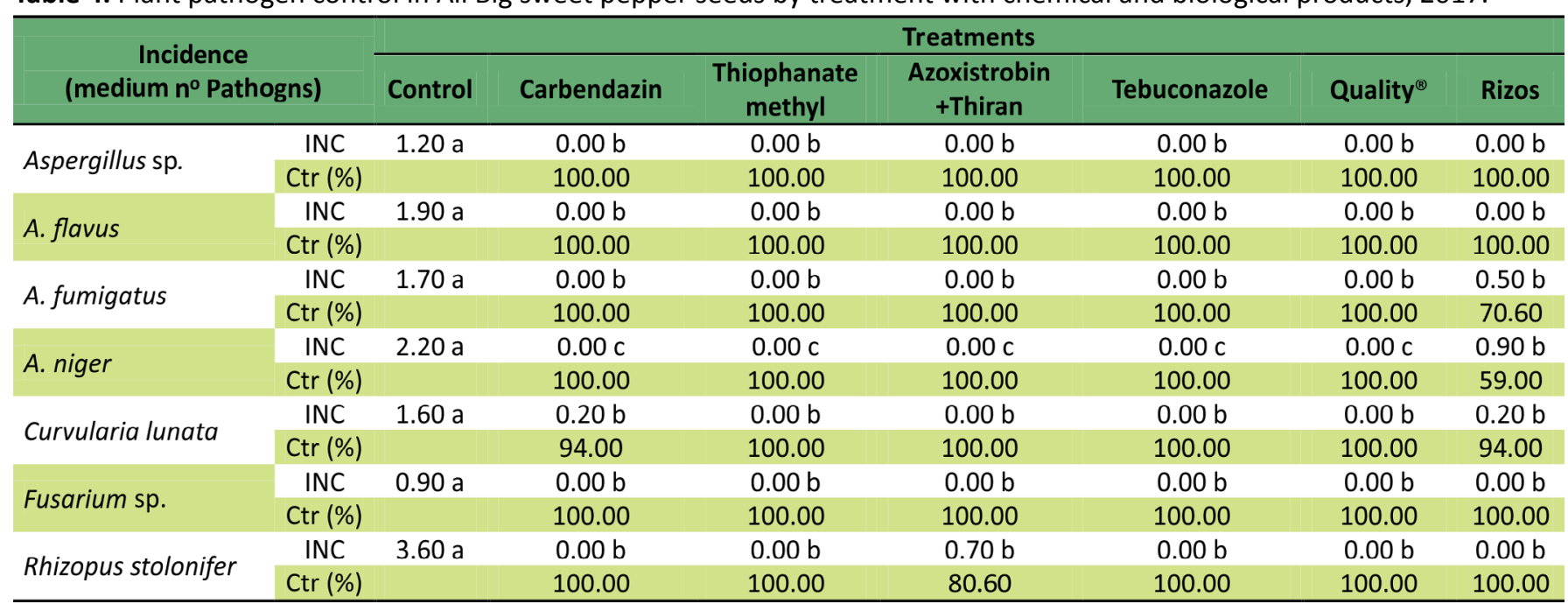

Where INC = incidence, $\mathrm{Ctr}=$ control. Values followed by the same letter do not differ by the Tukey test $(p \geq 0.05)$. Data transformed by $\mathrm{Vx}$. 
The products used were shown to be efficient in controlling the plant pathogens present in the sweet pepper seeds, especially the fungicides Thiophanate methyl and Tebuconazole and the Quality ${ }^{\circledR}$ biological product in controlling $100 \%$ of all the plant pathogens identified.

The identified fungi, belonging to the genera Aspergilus sp. Curvularia lunata Fusarium e Rhizopus sp., were controlled $100 \%$ by the fungicides Thiophanate methyl and Tubuconazole. Similar results were described by Fischer et al. (2012) when the effects were assessed of 10 fungicides on reduction of mycelial growth of the causal agents of anthracnose (C. gloeosporioides and $C$. acutatum) and guava black spot (Guignardia psidii Ullasa \& Rawal [Anamorfo: Phyllosticta psidiicola (Petrak)]), where the fungicides Carbendazim and Thiophanate methyl inhibited over $60 \%$ of the C. gloeosporioides growth, but for the $C$. acutatum isolates the fungicides Mancozebe, Thiophanate methyl and Captan were not efficient.

Treatment with Carbendazin controlled up to $100 \%$ of the plant pathogens and did not interfere in the seed germination. Different results were reported by Fantinel et al. (2015), Acca sellowiana (O. Berg) Burret seeds, observed that treatment with Carbendazin, although it erradicated the fungi Aspergillus flavus and A. niger, Phomopsis sp. and Alternaria sp., was toxic to seed germination.

The biological product Quality ${ }^{\circledR}$ eradicated all the fungi identified. Corroborating with these results, Lazarotto et al. (2013) observed that cedar seeds (Cedrella fissilis L.) treated with chemical and biological product based on Trichoderma sp. and the two combined (biological + chemical) eradicated the pathogen (Rhizoctonia sp.) that was naturally infecting the seeds. Oliveira et al. (2016) observed that fungitoxic activity of the antagonists Trichoderma sp. and $B$. subtilis, in vitro on Colletotrichum musae mycelial growth with reductions of $84.0 \%$ and $74.0 \%$, respectively, and in vivo the Trichoderma sp. isolates were more efficient with $56 \%$ anthracnose inhibition in the banana.

The plant pathogen fungi reproduction structures, the spores, are a large potential for infection in plants and are easily disseminated. Thus the results of this study indicate that the efficiency of the product is related to its capacity to inhibit the pathogenic agent, in the various action mechanisms of the chemical and biological products such as inhibiting the germination tube emission and in the degradation of the pathogen cell wall or by the release of volatile and nonvolatile secondary metabolites via hyperparisitism, in addition to competition for oxygen, nutrients and space.

\section{In vitro treatment with biological control}

In the in vitro experiment, with biological control, where the seeds were microbiolized with Bacillus isolates, the genera Aspergillus sp., Curvularia sp., Fusarium sp. and Rhizopus sp. predominated (Table 5). For most of the fungi identified, all the Bacillus isolates differed significantly from the control, with no differences except for the fungus Fusarium sp. that did not show statistical difference.

Microbiolization with Bacillus isolates controlled up to $100 \%$ of the fungi identified in all the seeds. Regarding the potential for plant pathogen reduction, the isolates of Bacillus, Bacillus pumilus and Bacillus licheniformis isolates microbiolized in soybean seeds also reduced the plant pathogens by $99.83 \%$ and $99.22 \%$, respectively (Bezerra et al., 2013).

Regarding the effect of the different Bacillus isolates on microbial antagonism, there was no significant difference among the isolates tested, but they were significantly efficient in reducing the fungus colonies.

There are several studies in the literature that confirm antagonism of the genus Bacillus to plant pathogens, such as the findings by Oliveira et al. (2016), when testing the inhibition potential of the antagonists Levedura IA8 (L), Trichoderma sp. (TR) and $B$. subtilis (Bs) in banana anthracnose (Colletotrichum musae) control. Rios Velasco et al. (2016) also observed that Bacillus species cause the inhibition of Botrytis cinerea Pers. fungus colonies with up to $69 \%$ root growth inhibition (PRGI).

In the present research, $B$. methylotrophicus eradicated all the plant pathogens, including the fungus Fusarium sp. It is

Table 5. Plant pathogen control associated to the All Big sweet pepper seeds, microbiolized with Bacillus sp. isolates. 2017.

\begin{tabular}{|c|c|c|c|c|c|c|c|}
\hline \multirow{2}{*}{\multicolumn{2}{|c|}{$\begin{array}{c}\text { Incidence } \\
\text { (medium no Pathogens) }\end{array}$}} & \multicolumn{6}{|c|}{ Treatments } \\
\hline & & \multirow{2}{*}{$\frac{\text { Control }}{1.30 \mathrm{a}}$} & \multirow{2}{*}{$\frac{\text { MGSS } 274}{0.00 \mathrm{~b}}$} & \multirow{2}{*}{$\frac{\text { MGSS } 272}{0.00 \mathrm{~b}}$} & \multirow{2}{*}{$\frac{\text { MGSS } 273}{0.00 \mathrm{~b}}$} & \multirow{2}{*}{$\frac{\text { Bacillus sp. }}{0.00 \mathrm{~b}}$} & \multirow{2}{*}{$\frac{\text { MG SS271 }}{0.00 \mathrm{~b}}$} \\
\hline & INC & & & & & & \\
\hline Aspergillus sp. & $\operatorname{Ctr}(\%)$ & & 100.00 & 100.00 & 100.00 & 100.00 & 100.00 \\
\hline A. flavus & $\operatorname{Ctr}(\%)$ & & 100.00 & 87.50 & 100.00 & 70.80 & 100.00 \\
\hline A. fumigatus & INC & $2.20 \mathrm{a}$ & $0.00 \mathrm{~b}$ & $0.00 \mathrm{~b}$ & $0.40 \mathrm{~b}$ & $0.00 \mathrm{~b}$ & $0.00 \mathrm{~b}$ \\
\hline A. niger & $\operatorname{Ctr}(\%)$ & & 100.00 & 85.70 & 78.60 & 78.60 & 85.70 \\
\hline \multirow{2}{*}{ Curvularia lunata } & INC & $2.10 \mathrm{a}$ & $0.00 \mathrm{~b}$ & $0.30 \mathrm{~b}$ & $0.00 \mathrm{~b}$ & $0.00 \mathrm{~b}$ & $0.20 \mathrm{~b}$ \\
\hline & $\operatorname{Ctr}(\%)$ & & 100.00 & 85.70 & 100.00 & 100.00 & 90.50 \\
\hline \multirow{2}{*}{ Fusarium sp. } & INC & $0.90 \mathrm{a}$ & $0.00 \mathrm{a}$ & $0.30 \mathrm{a}$ & $0.20 \mathrm{a}$ & $0.00 \mathrm{a}$ & $0.00 \mathrm{a}$ \\
\hline & $\operatorname{Ctr}(\%)$ & & 100.00 & 66.70 & 77.80 & 100.00 & 100.00 \\
\hline Rhizopus stolonifer & INC & $3.00 \mathrm{a}$ & $0.00 \mathrm{~b}$ & $0.00 \mathrm{~b}$ & $0.00 \mathrm{~b}$ & $0.00 \mathrm{~b}$ & $0.00 \mathrm{~b}$ \\
\hline
\end{tabular}

Where INC = incidence, $\mathrm{Ctr}=$ control, MSS $272=$ B. polymyxa; MSS $273=B$. pentothenticus; MSS $271=B$. cereus e MSS $274=B$. methylotrophicus. Values followed by the same letter do not differ by the Tukey test $(p \geq 0.05)$. Data transformed by $v x$. 
important to emphasize that the species $B$. methylotrophicus is mentioned in the literature because of its great biocontrol potential, due to its greater antagonic effect on plant pathogens (Rios Velasco et al., 2016; Paz et al., 2018).

In Santa Cruz cultivar tomato seeds, microbiolization with $B$. methylotrophicus helped induce systemic resistance in plants to fusarium wilt (Fusarium oxysporum f. sp. lycopersici Schlecht Snyder \& Hansen) by the activating the enzymes peroxidase and polyphenoloxydase and the disease was reduced by $75 \%$ (Campos Neto et al., 2018). B. methylotrophicus isolates also presented highly efficient fungistatic action on the mycelial growth of Corynespora cassiicola (Berk \& Curt.) Wei causal agent of the papaya tree white spot (Paz et al., 2018).

Bacillus isolates present great potential for biocontrol, given their capacity to produce $1 \mathrm{~g}$ of anti-fungus metabolites such as surfactin, iturins and furgicins that are lipopeptide families, with anti-fungicide capacity and growth inhibition on a wide variety of plant pathogens (Lanna Filho, 2010). Thus, the Bacillus isolates may have acted in different ways or used different action mechanisms to inhibit the identified pathogens, either by competition, antibiotic production or the release of volatile compounds either alone or by the interaction of these mechanisms.

\section{Anthracnose management in sweet pepper}

Assessments made at 3, 8, 13 and 18 days after inoculating the pathogen (DAI) were not significantly different among the treatment severity means (Figure 2). However, at 23 days after inoculation, significant differences were observed among the treatments. The control treatment presented mean $4.35 \%$ severity, the treatments based on basil plant extract at $5.00 \%$; the Bacillus methylotrophicus isolates and the commercial Quality ${ }^{\circledR}$ biological product presented the same results with the lowest severity values, and were statistically different from the control $(p<0.008)$.

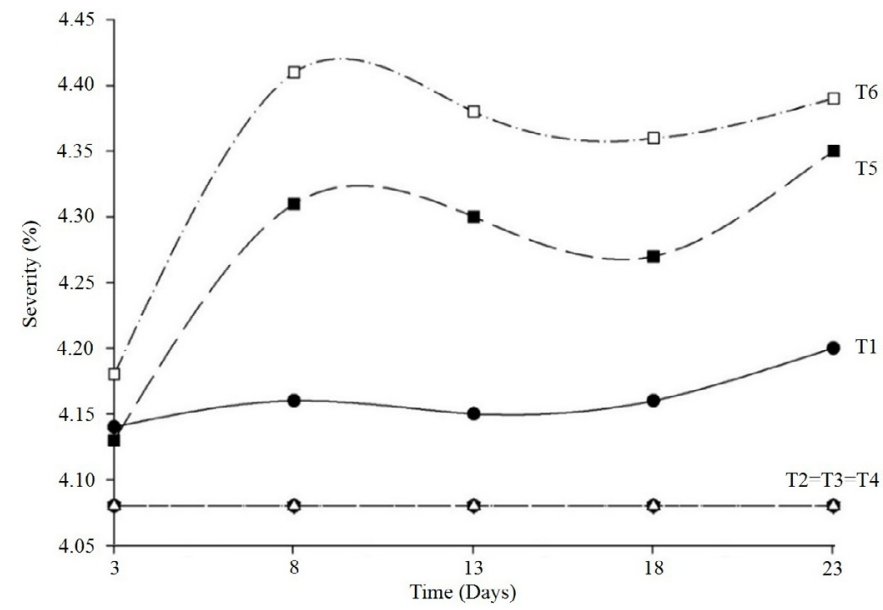

Where: $\mathrm{CV}(\%)=3.33 ; \mathrm{T} 1$ = Heat Treatment $\left(45^{\circ} \mathrm{C} 25 \mathrm{~min}.\right) ; \mathrm{T} 2$ = basil extract at $5 \%$; $\mathrm{T} 3=$ Bacillus methylotrophicus, B47; $\mathrm{T} 4=$ Quality $^{\circledR}$ (Trichoderma asperellum); $\mathrm{T} 5=$ Thiophanate methyl; $\mathrm{T} 6=$ Control. Values transformed by $\mathrm{v}$.

Figure 2. Anthracnose severity caused by $C$. gloeosporioides, in the All Big sweet pepper cultivar, in function of the seed treatments in the assessment times, 2018.
The heat treatments at $45^{\circ} \mathrm{C} / 25$ minutes and Thiophanate methyl presented higher anthracnose severity values in the plants, $4.16 \%$ and $4.35 \%$, respectively, which were equivalent to the control and did not differ from the other treatments (Figure 3).

The treatments based on B. methylotrophicus, Quality ${ }^{\circledR}(T$. asperellum) and basil aqueous extract reduced anthracnose severity in sweet pepper and showed the inhibition potential of these treatments on the initial development of plant pathogens, with significant effect regarding the other treatments. Campos Neto et al. (2018) observed that $B$. methylotrophicus microbiolization on Santa Cruz cultivar tomato seeds reduced Fusarium wilt by almost $80 \%$ and also activated the enzymes peroxidase and polyphenoloxidase that induced the systemic resistance of the plants to the disease.

Oliveira et al. (2016) observed that the biocontrol agents Trichoderma sp. and Bacillus subtilis were efficacious in controlling banana anthracnose (Colletotrichum musae) in vivo, confirming the inhibition potential and the highest efficiency was obtained with Trichoderma sp. isolate that inhibited about $56 \%$ of the disease. Bacillus isolates in treatment of chick cowpea seeds for Rhizoctonia solani, control, etiological agent of Mela, in vivo, retarded disease incidence and reduced the leaf fall percentage (Schurt et al., 2017).

Similar results to those of the present research with commercial products based on Trichoderma ssp. were reported by Fantinel et al. (2018) in the in vitro control of Colletotrichum siamense, mainly by Trichoderma koningiopsis and indicated this species, with potential for studies as a biocontrol agent of guava anthracnose. In a study on biological control of tomato plant late blight caused by Phytophthora infestans (Mont.) de Bary, using Trichoderma harzianum and T. longibrachiatum isolates, the results up to 50 days after transplant showed the protective action of these antagonists against late blight (Souza et al., 2014). The efficiency of these Trichoderma species in

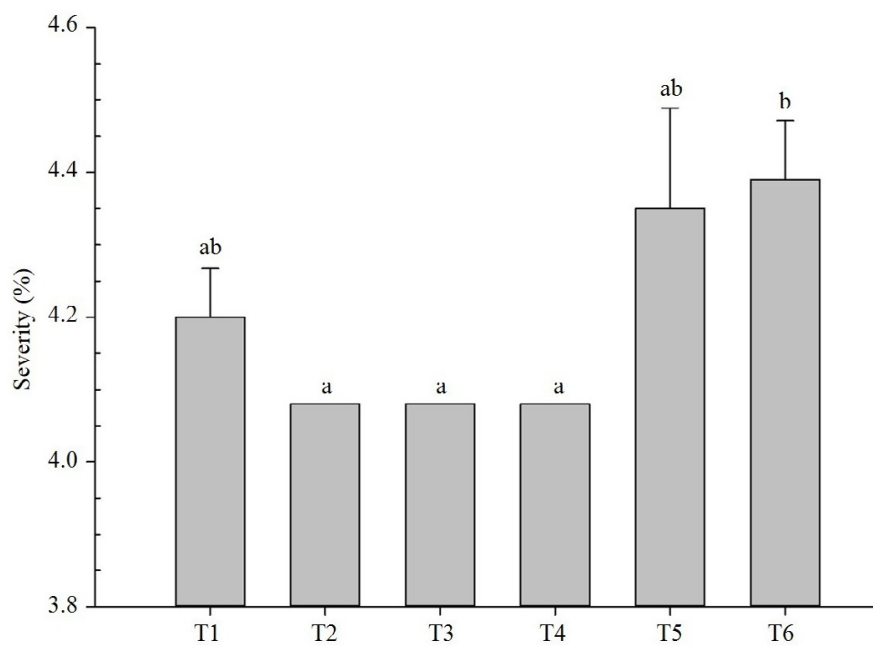
Where: $\mathrm{CV}$ (\%): 3,77; $\mathrm{T} 1=$ heat treatment $\left(45^{\circ} \mathrm{C} 25 \mathrm{~min}\right.$ ); $\mathrm{T} 2=$ basil extract (5\%); $\mathrm{T} 3=$ Bacillus methylotrophicus, B47; T4 = Quality ${ }^{\circledR}$; 5 = Thiophanate methyl; T6 = Control. Means followed by the same letter do not differ by the Tukey test $(p \geq 0.05)$. Values transformed by $\mathrm{vx}$.

Figure 3. Effect of treatments on anthracnose caused by $C$. gloeosporioides in the All Big sweet pepper cultivar, at $23 \mathrm{DAI}$, 2018. 
disease control may be related to the peculiar characteristics of the species, such as the capacity to dribble the pathogen defense lines, competitiveness with the soil biota and resistance to abiotic factors (Bae \& Knudsen, 2005).

In the present study, analysis of variance of the area underneath the disease progress curve (AUDPC) did not show significant differences between the treatments. The treatments that presented the lowest percentages of the area affected by the disease were basil at $5 \%, B$. methylotrophicus isolate and Quality ${ }^{\circledR}$ (T. asperellum), around 51.00 . Heat treatment at $45^{\circ} \mathrm{C} / 25 \mathrm{~min}$. and Thiophanate methyl, resulted in values of 52.01 and 53.37 AUDPC, respectively.

The non-significance of the effect of treatments on AUDPC may be associated to the fact that the treatments did not present significant differences between the means of the assessments at 3, 813 and 18 days after inoculation. The AUDPC variable is used by some authors because it represents the total epidemic, because it considers the disturbances that the crop is subject to at all stages of development (Hikishima et al., 2010; Marcuzzo et al., 2019). However, because it is an integral variable, obtained only after carrying out all the assessments of the end of the cycle, it is not possible to obtain responses on the damage during harvest, that may under or overestimate the results (Hikishima et al., 2010).

These results allow inference on the need to assess methods and techniques of seed treatments and the association of methods with pre-and post harvest application to make sweet pepper cropping feasible with efficient means of anthracnose control, such as non-pollutant and atoxic alternatives with no residual effect.

\section{Conclusions}

The alternative methods based on basil and cinnamon extracts, the use of heat therapy and adopting biological control agents based on Bacillus methylotrophicus and Trichoderma asperellum presented greater fungistatic and fungitoxic action and controlled the plant pathogens, in sweet pepper seeds.

The results obtained are an important alternative with potential to treat sweet pepper seeds and a possible support for future use in integrated disease management programs.

\section{Acknowledgements}

The authors thank the Maranhão Foundation of Support to Research and Scientific and Technological Development (FAPEMA) for funding the project and to CAPES for the student grants.

\section{Literature Cited}

Araújo, N.A.F.; Vieira, J.M.; Moura, M.R.; Pessoa, W.R.L.S.; Barguil, B.M. Pathogenicity and aggressiveness of Colletotrichum gloeosporioides isolates in ornamental pepper. Pesquisa Agropecuária Tropical, v.46, n.3, p.321-326, 2016. https://doi. org/10.1590/1983-40632016v4641483.
Bae, Y.S.; Knudsen, G.R. Soil microbial biomass influence on growth and biocontrol efficacy of Trichoderma harzianum. Biological Control, v.32, n. 2, p.236-242, 2005. https://doi.org/10.1016/j. biocontrol.2004.10.001.

Bezerra, G.A.; Macedo, D.A.; Nascimento, I.O.; Sousa, T.P.; Costa, N.B.; Sousa, L.F.R.A. Uso de Bacillus spp. no controle de fitopatógenos em sementes de soja variedade BRS Valiosa RR. Agroecossistemas, v.5, n.1, p.68-73, 2013. https://doi. org/10.18542/ragros.v5i1.1414.

Braga, M.P.; Olinda, R.A.; Homma, S.K.; Dias, C.T. Relações entre tratamento térmico, germinação, vigor e sanidade de sementes de tomate. Revista Brasileira de Sementes, v.32, n.1, p.101-110, 2010. https://doi.org/10.1590/S0101-31222010000100012.

Brasil. Ministério da Agricultura e Reforma Agrária. Regras para análise de sementes. Brasília: SNDA; DNVD; CLAV, 2009. 365p.

Brito, N.M.; Nascimento, L.C. Potencial fungitóxico de extratos vegetais sobre Curvularia eragrostidis (P. Henn.) Meyer in vitro. Revista Brasileira de Plantas Medicinais, v.17, n.2, p.230-238, 2015. https://doi.org/10.1590/1983-084X/10_057.

Camatti-Sartori, V.; Magrini, F.E.; Crippa, L.B.; Marchett, C.; Venturin, L.; Silva-Ribeiro, R.T. Avaliação in vitro de extratos vegetais para o controle de fungos patogênicos de flores. Revista Brasileira de Agroecologia, v.6, n.2, p.117-122, 2011. http://revistas. aba-agroecologia.org.br/index.php/rbagroecologia/article/ view/9904/6963. 10. Mar. 2020.

Campos Neto, J.R.M.; Chaves, R.R.; Sardinha, D.H.S.; Melo, L.G.L.; Rodrigues, A.A.C. Bacterial Formulations in Induction of Resistance and Growth Promotion of Tomato Plants. Journal of Agricultural Science, v.10, n.10, p.493-503, 2018. https://doi. org/10.5539/jas.v10n10p493.

Associação Brasileira dos Produtores Exportadores de Frutas e Derivados - Abrafrutas. Confederação da Agricultura e Pecuária do Brasil - CNA. Cenário Hortifruti Brasil 2018. Brasília: Abrafrutas, 2018. 94p. https://abrafrutas.org/wp-content/ uploads/2019/09/Relatorio-Hortifruti.pdf. 15 Mar. 2020.

Costa, I.J.S.; Soares, E.P.S.; Sales, N.L.P.; Azevedo, D.M.Q.; Rocha, A.P.; Aquino, C.F. Tratamento de sementes de tomate cereja visando sanidade germinação através da termoterapia. Cadernos de Agroecologia, v.6, n.2, p.1-5, 2011. http://revistas.abaagroecologia.org.br/index.php/cad/article/view/11140. 11 Mar. 2020.

Cunha, R.P.; Carvalho, I.L.; Olsen, D.; Vieira, J.F.; Soares, V.N.; Tunes, L.M. Termoterapia no controle de patógenos associados às sementes de abóbora. Revista Tecnologia \& Ciência Agropecuária, v.11, n.2, p.53-57, 2017. http://revistatca.pb.gov.br/edicoes/ volume-11-2017/v-11-n-2-junho-2017/tca11210.pdf. 10 Mar. 2020.

Di Rienzo, J.A.; Casanoves, F.; Balzarini, M.G.; Gonzalez, L.; Tablada, M.; Robledo, C.W. InfoStat versión 2018. Córdoba: InfoStat Group; Facultad de Ciencias Agropecuarias; Universidad Nacional de Córdoba, 2018. http://www.infostat.com.ar. 10 Dez. 2019.

Fantinel, V.S.; Muniz, M.F.B.; Poletto, T.; Dutra, A.F.; Krahn, J.T.; Favaretto, R.F.; et al. Biocontrole in vitro de Colletotrichum siamense utilizando Trichoderma spp. e Bacillus thuringiensis var. kurstaki. Ciência Agrícola v.16, n.3, p.43-50, 2018. https://doi. org/10.28998/rca.v16i3.4818. 
Fantinel, V.S.; Oliveira, L.M.; Casa, R.T.; Rocha, E.C.; Schneider, P.F.; D.V. Tratamentos de sementes de goiaba-serrana (Acca sellowiana): efeito na incidência de fungos e na germinação. Revista Brasileira de Biociências, v.13, n.2, p.84-89, 2015. http://www.ufrgs.br/ seerbio/ojs/index.php/rbb/article/view/3178/1276. 10 Mar. 2020.

Ferreira, D.S.; Pires, L.M.; Oliveira, T.A.S.; Peixoto, N.; Carvalho, D.D.C. Ocorrência de fungos em sementes de feijão 'red mexican' e seu efeito na germinação. Scientia Agraria Paranaensis, v.16, n.4, p.542-545, 2017. https://doi.org/10.18188/1983-1471/sap. v16n4p542-545.

Fischer, I.H.; Silva, B.L.; Soares, A.R.; Arruda, M.C.; Parisi, M.C.M.; Amorim, L. Efeito de fungicidas e produtos alternativos no controle da antracnose e da pinta preta da goiaba. Semina: Ciências Agrárias, v.33, supl. 1, p.2753-2766, 2012. https://doi. org/10.5433/1679-0359.2012v33Supl1p2753.

Flávio, N.S.D.S.; Sales, N.L.P.; Aquino, C.F.; Soares, E.P.S.; Aquino, L.F.S.; Catão, C.R.M. Qualidade sanitária e fisiológica de sementes de sorgo tratadas com extratos aquosos e óleos essenciais. Semina: Ciências Agrárias, v.35, n.1, p.7-20, 2014. https://doi. org/10.5433/1679-0359.2014v35n1p7.

Govindachari, T.R.; Suresh, G.; Gopalakrishnan, G.; Banumathy, B.; Masilamani, $S$. Identification of antifungical compounds from the seed oil of Azadirachta indica. Phytoparasitica, v.26, n.2, p.109116, 1998. https://doi.org/10.1007/BF02980677.

Hikishima, M.; Canteri, M.G.; Godoy, C.V.; Koga, L.J.; Silva, A.J. Quantificação de danos e relações entre severidade, medidas de refletância e produtividade no patossistema ferrugem asiática da soja. Tropical Plant Pathology, v.35, n.2, p.096-103, 2010. https:// doi.org/10.1590/S1982-56762010000200004.

Koroch, A.R.; Simon, J.E.; Juliani, H.R. Essential oil composition of purple basils, their reverted green varieties (Ocimum basilicum) and their associated biological activity. Industrial Crops and Products, v.107, p.526-530, 2017. https://doi.org/10.1016/j.indcrop.2017.04.066.

Lanna Filho, R.; Ferro, H.M.; Pinho, R.S.C. Controle biológico mediado por Bacillus subtilis. Revista Trópica Ciências Agrárias e Biológicas, v.4, n.2, p.12-20, 2010. https://doi.org/10.0000/rtcab.v4i2.145.

Lazarotto, M.; Muniz, M.F.B.; Beltrame, R.; Santos, A.F.; Müller, J.; Araújo, M.M. Tratamentos biológico e químico em sementes de Cedrela fissilis para controle de Rhizoctonia sp. Cerne, v.19, n.1, p.169-175, 2013. https://doi.org/10.1590/S0104-77602013000100020.

Ludwig, J.; Moura, A.B. Controle biológico da queima-das-bainhas em arroz pela microbiolização de sementes com bactérias antagonistas. Fitopatologia Brasileira, v.32, n.5, p.381-386, 2007. https://doi.org/10.1590/S0100-41582007000500002.

Maguire, J.D. Speed of germination-aid in selection and evaluation for seedlig emergence and vigor. Crop Science, v.2, n.1, p.176-177, 1962. https://doi.org/10.2135/ cropsci1962.0011183X000200020033x.

Marcuzzo, L.L.; Kotkoski, B.; Wernke, C. Progresso da queima das pontas das folhas da cebola sob diferentes programas de aplicação de fungicidas. Summa Phytopathologica, v.45, n.4, p.415-419, 2019. https://doi.org/10.1590/0100-5405/206961.

Mckinney, H.H. Influência da temperatura e umidade do solo na infecção de plântulas de trigo por Helminthosporium sativum. Journal of Agricultural Research, v.26, n.5, p.195-218, 1923. https://doi.org/10.1590/S0100-41582006000600007.
Monteiro Neto, J.L.L.; Araújo, W.F; Vilarinho, L.B.O.; Silva, E.S.; Araújo, W.B.L.; Sakazaki, R.T. Produção de mudas de pimentão (Capsicum annuum L.) em diferentes ambientes e substratos. Revista Brasileira de Ciências Agrárias, v.11, n.4, p.289-297, 2016. https://doi.org/10.5039/agraria.v11i4a5395.

Oliveira, E.S.; Viana, F.M.P.; Martins, M.V.V. Alternativas a fungicidas sintéticos no controle da antracnose da banana. Summa Phytopathologica, v.42, n.4, p.340-350, 2016. https://doi. org/10.1590/0100-5405/2000.

Paiva, C.T.C.; Silva, J.B.; Dapont, E.C.; Alves, C.Z.; Carvalho, M.A.C. Qualidade fisiológica e sanitária de sementes comerciais de alface e repolho. Revista de Ciências Agroambientais, v.14, n.1, p.53-59, 2016. https://periodicos.unemat.br/index.php/rcaa/ article/view/1410. 11 Mar. 2020.

Paz, D.S.; Araújo, J.R. G.; Rodrigues, A.A.C. Silva, E.K.C.; Diniz, N.B. Reação de genótipos de mamoeiro a mancha-alvo e atividade de extratos vegetais e Bacillus spp. sobre Corynespora cassiicola. Revista Brasileira de Fruticultura, v.40, n.1, e-927, 2018. https:// doi.org/10.1590/0100-29452018927.

Pereira, M.J.Z.; Massola Junior, N.S.; Sussel, A.A.B.; Sala, F.C.; Costa, C.P.; Boiteux, L.S. Reação de acessos de Capsicum e de progênies de cruzamentos interespecíficos a isolados de Colletotrichum acutatum. Horticultura Brasileira, v.29, n.4, p.569-576, 2011. https://doi.org/10.1590/S0102-05362011000400021.

Pereira, R.B.; Silva P.P.; Nascimento, W.M. Pinheiro, J.B. Tratamento de sementes de hortaliças. Brasília: Embrapa, 2015. 16p. (Embrapa Hortaliças. Circular Técnica, 140). http://ainfo.cnptia.embrapa. br/digital/bitstream/item/127656/1/CT-140X.pdf. 29 Mar. 2020.

Piveta, G.; Menezes, V.O.; Pedroso, D.C.; Muniz, M.F.B.; Blume, E.; Wielewicki, A.B. Superação de dormência na qualidade de sementes e mudas: influência na produção de Senna multijuga (L.C. Rich.) Irwin \& Barneby. Acta Amazônica, v.40, n.2, p.281-288, 2010. https://doi.org/10.1590/S0044-59672010000200006.

Reverberi, M.; Ricelli, A.; Zjalic, S.; Fabbri, A.A.; Fanelli, C. Natural functions of mycotoxins and control of their biosynthesis in fungi. Applied Microbiology and Biotechnology, v.87, n.3, p.899-911, 2010. https://doi.org/10.1007/s00253-010-2657-5.

Rios-Velasco, C.; Caro-Cisneros, J.M.; Berlanga-Reyes, D.I.; RuizCisneros, M.F.; Ornelas-Paz, J.J.; Salas-Marina, M.Á.; GuerreroPrieto, V.M. Identification and antagonistic activity in vitro of Bacillus spp. and Trichoderma spp. isolates against common phytopathogenic fungi. Revista Mexicana de Fitopatología, v.34, n.1, p.84-99, 2016. https://doi.org/10.18781/R.MEX.FIT.1507-1.

Santos, L.A.; Faria, C.M.D.R.; Marek, J.; Duhatschek, E.; Martinichen, D. Radioterapia e Termoterapia como tratamentos de sementes de soja. Applied Research \& Agrotechnology, v.9, n.2, p.37-44, 2016. https://doi.org/10.5935/PAeT.V9.N2.04.

Schurt, D.; Seabra, S.S.S.; Silva, A.D.; Stéfanny, A.M.; Medeiros, F.H.V. Tratamentos químicos e biológicos de sementes para Controle da mela do feijão-caupi. Revista Agri-Environmental Sciences, v.3, n.1, p.30-36, 2017. https://revista.unitins.br/index.php/agrienvironmental-sciences/article/view/453/360. 20 Mar. 2020.

Shaner, G.; Finney, R.E. The effect of nitrogen fertilization on the expression of slow-mildewing resistance in knox wheat. Phytopathology, v.67, n.8, p.1051-1056, 1977. https://doi. org/10.1094/Phyto-67-1051. 
Souza, J.R; Rebouças, T.N.H.; Luz, J.M.Q.; Amaral, C.L.F.; Figueiredo, R.M.; Santana, C.M.P. Potencialidade de fungicidas biológicos no controle de requeima do tomateiro. Horticultura Brasileira, v.32, n.1, p.115119, 2014. https://doi.org/10.1590/S0102-05362014000100020.

Torres, S.B.; Minami, K. Qualidade fisiológica de sementes de pimentão. Scientia Agricola, v.57, n.1, p.109-112, 2000. https:// doi.org/10.1590/S0103-90162000000100018.

Trecha, C.O.; Lovatto, P.B.; Mauch, C.R. Entraves do cultivo convencional e as potencialidades do cultivo orgânico do pimentão no Brasil. Revista Thema, v.14, n.3, p.291-302, 2017. https://doi.org/10.15536/thema.14.2017.291-302.458.
Vieira, B.N.P.; Santos, B.R.; Sousa, B.C.M.; Vieira, T.A.; Lustosa, D.C. Qualidade fisiológica e sanitária de sementes de pimentão comercializadas em Santarém, Pará. Agroecossistemas, v.10, n.1, p.241-252, 2018. https://doi.org/10.18542/ragros.v10i1.4991.

Wuaden, C.R.; Gaio, I.; Sperhacke, T.; Barro, J.P.; Milanesi, P.M. Atividade antifúngica do extrato alcoólico de própolis, álcool de cereais e do óleo essencial de manjericão sobre Botrytis cinerea. Colloquium Agrariae, v.14, n.2, p.48-55, 2018. http://revistas. unoeste.br/index.php/ca/article/view/2003. 25 Jan. 2020.

Zambolim, L.; Vale, F.X.R.; Costa, H. Controle integrado de doenças de hortaliças. Viçosa: UFV, 1997. 134p. 